Article

\title{
Species-Specific Molecular Detection of the Root Knot Nematode Meloidogyne luci
}

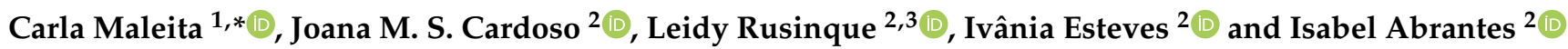 \\ 1 Department of Chemical Engineering, Chemical Process Engineering and Forest Products Research Centre, \\ University of Coimbra, Rua Sílvio Lima, Pólo II—Pinhal de Marrocos, 3030-790 Coimbra, Portugal \\ 2 Department of Life Sciences, Calçada Martim de Freitas, University of Coimbra, Centre of Functional Ecology, \\ 3000-456 Coimbra, Portugal; joana.cardoso@uc.pt (J.M.S.C.); leidy.rusinque@iniav.pt (L.R.); \\ iesteves@uc.pt (I.E.); isabel.abrantes@uc.pt (I.A.) \\ 3 Instituto Nacional de Investigação Agrária e Veterinária (INIAV, I.P.), 2780-159 Oeiras, Portugal \\ * Correspondence: carla.maleita@uc.pt
}

check for updates

Citation: Maleita, C.; Cardoso, J.M.S.; Rusinque, L.; Esteves, I.; Abrantes, I. Species-Specific Molecular Detection of the Root Knot Nematode Meloidogyne luci. Biology 2021, 10, 775. https://doi.org/10.3390/biology 10080775

Academic Editor: James White

Received: 12 July 2021

Accepted: 11 August 2021

Published: 14 August 2021

Publisher's Note: MDPI stays neutral with regard to jurisdictional claims in published maps and institutional affiliations.

Copyright: (c) 2021 by the authors. Licensee MDPI, Basel, Switzerland. This article is an open access article distributed under the terms and conditions of the Creative Commons Attribution (CC BY) license (https:// creativecommons.org/licenses/by/ $4.0 /)$.
Simple Summary: The root knot nematode Meloidogyne luci has been identified in various countries around the world parasitizing economically important crops. Due to its potential to cause serious damage to agriculture, the need for an accurate diagnosis at the species level has become mandatory. In the present study, a specific amplification product on $M$. luci was obtained from a random amplified polymorphic DNA (RAPD) analysis. The DNA was sequenced and converted into a sequence characterized amplified region (SCAR) marker used for the species-specific molecular detection of this root knot nematode. The developed methodology is essential to monitoring the distribution and spread of M. luci in order to implement future effective and integrated pest management programs.

Abstract: Meloidogyne luci has been identified in various countries around the world parasitizing economically important crops and, due to its potential to cause serious damage to agriculture, was included in the European and Mediterranean Plant Protection Organization Alert List in 2017. This species shares morphological and molecular similarities with M. ethiopica and M. inornata, and a M. ethiopica group was therefore established. Although specific primers for the DNA amplification of species belonging to the M. ethiopica group have been developed previously, the primers were not species-specific, so molecular markers for the specific detection of M. luci are still needed. The objective of this study was to develop a SCAR marker for the detection of M. luci and the discrimination from other Meloidogyne spp. based on the intraspecific variability found in RAPD markers. RAPD screening of M. luci and M. ethiopica genome was used for the identification of a specific amplification product on $M$. luci, which was cloned, sequenced and converted into a SCAR marker. The specificity of the designed primers (Mlf/r) was tested and produced a fragment $(771 \mathrm{bp})$ for all nine $M$. luci isolates with no amplification for the other nine Meloidogyne spp., including M. ethiopica and M. inornata. Additionally, the proper amplification of the M. luci SCAR-marker was also successful with DNA from galls of $M$. luci infected tomato roots. The results obtained in this study reveal that the specific molecular detection of $M$. luci was achieved and that the developed methodology can be used for routine diagnosis purposes, which are essential to monitoring the distribution and spread of $M$. luci in order to implement future effective and integrated nematode pest management programs.

Keywords: diagnosis; RAPD; species-specific primer; sequence characterized amplified region

\section{Introduction}

Root knot nematodes (RKN), Meloidogyne spp., comprise one of the most successful groups of plant parasites, responsible for worldwide crop losses of billion dollars annually [1]. The impact of RKN in agricultural areas strengthens the need for an accurate diagnosis at the species level. At the moment, the genus Meloidogyne includes 105 described 
species of which four are considered the most common (M. arenaria, M. hapla, M. incognita and $M$. javanica) due to their wide distribution and host range, but many others have been recognized as emerging species [1-3]. For instance, $M$. chitwoodi, M. enterolobii, M. fallax and M. mali are included in the European and Mediterranean Plant Protection Organization (EPPO) A2 List of pests recommended for regulation as quarantine organisms, whereas M. ethiopica, M. graminicola and M. luci, based on their potential to cause serious damage to agriculture, were added to the EPPO Alert List [4].

In the past, RKN identification was frequently centered on microscopic examination and female perineal pattern analyses, but these methods are often unreliable and require specialized skills due to the inter- and intraspecific RKN variability and to the frequent occurrence of more than one species in the same sample [5,6]. Currently, the biochemical electrophoretic analysis of non-specific esterases is a widely used method used to differentiate Meloidogyne species, with many species-specific isozyme patterns already published [6] However, the need for fully developed female nematodes in good condition, the observation of intraspecific isozyme phenotypic variability, the resemblance between species based on gel comparative analysis of esterase patterns, the discovery of new patterns, timeconsuming methodology and the difficulty of processing a large number of samples are all constraints that complicate RKN biochemical identification. Thus, additional information provided by DNA-based methodologies are crucial in RKN diagnostics. Random amplified polymorphic DNA (RAPD), restriction fragment length polymorphism variation (RFLP) and sequence characterized amplified regions (SCAR) markers have been developed, and different DNA regions have been used for the identification and phylogenetic analysis of RKN [7-16].

The emerging RKN M. luci, obtained from lavender roots (Lavandula spica L.) in Brazil, was described in 2014 [17]. This species shares some morphological and biochemical similarities with M. ethiopica and M. inornata, which led to the initial misidentification of several M. luci isolates in Europe as M. ethiopica [15,16]. Meloidogyne luci has been identified in various countries around the world, namely Argentina, Brazil, Bolivia, Chile, Ecuador, Greece, Guatemala, Iran, Italy, Portugal, Slovenia and Turkey, and is associated with more than 40 economically important crops, ornamentals, herbs and weeds [15,17-34].

Important crop losses have been referred on tomato, with reports of more than $80 \%$ crop decline caused by M. luci in a greenhouse in Slovenia [26]. On potato, the pathogenicity of $M$. luci was studied in 16 commercial cultivars, and all the cultivars were susceptible to this nematode, possessing relatively high pest reproduction factors [27]. Recently, it was shown that $M$. luci can cause latent infestation without visible infestation symptoms on the surface of potato tubers or severe tuber infestation with visible infestation symptoms [34].

In the present study, a suitable and accurate molecular method for the detection of M. luci is presented, discriminating this species from the closely related M. ethiopica and $M$. inornata. The efficient and fast identification of $M$. luci is essential to monitoring its distribution and spread and to implementing future effective and integrated pest management programs.

\section{Materials and Methods}

\subsection{Nematode Isolates}

Nine M. luci isolates from different origins and hosts were used in this study. Nine isolates from other RKN species were also included for the comparison and validation of the species-specific detection (Table 1).

All of the isolates were selected from the collection of the NEMATO-lab (CFE-UC) and maintained on tomato (Solanum lycopersicum L., cv. Coração-de-Boi) by periodic subculturing in a growth chamber $\left(\sim 25^{\circ} \mathrm{C} ; 12 \mathrm{~h}\right.$ photoperiod) by transferring the culture, every 2 months, to new tomato seedlings. 
Table 1. Meloidogyne isolates: hosts and geographic origin.

\begin{tabular}{|c|c|c|c|}
\hline Species (Isolate Code) ${ }^{a}$ & Host Plant & Geographic Origin & Reference \\
\hline M. luci(PtL1) & Solanum tuberosum L. & Coimbra & [27] \\
\hline (PtL2) & Oxalis corniculata $\mathrm{L}$. & Montemor-o-Velho & [30] \\
\hline (PtL3) & Cordyline australis (Forst f.) Hook. F & Figueira da Foz & {$[30]$} \\
\hline$(\mathrm{BrL})$ & Phaseolus vulgaris L. & Paraná State & [25] \\
\hline (GrL1) & Zea mays L. & Kavalla & {$[15,21]$} \\
\hline (GrL2) & Actinidia sp. & Kavalla & {$[15,21]$} \\
\hline (ItL) & S. lycopersicum L. & Pontecagnano & {$[15,22]$} \\
\hline$(\mathrm{SvL})$ & S. lycopersicum L. & Dornberk & {$[15,18]$} \\
\hline$(\operatorname{TrL})$ & Cucumis sativus L. & Çarsamba & {$[15,23]$} \\
\hline M. arenaria $(\mathrm{PtA})$ & Crassula multicava Lem. & Coimbra & - \\
\hline M. chitwoodi (PtCh) & S. tuberosum L. & Porto & [35] \\
\hline M. enterolobii (PtEn) & Cereus hildmannianus K. Schum. & Montemor-o-Velho & [36] \\
\hline M. ethiopica (BrEt) & Actinidia deliciosa (Chevalier) Liang \& Ferguson & Rio Grande do Sul State & [37] \\
\hline M. hapla (PtHa) & S. lycopersicum L. & Montemor-o-Velho & - \\
\hline M. hispanica (PtHi) & Ficus carica $\mathrm{L}$. & Setúbal & [38] \\
\hline M. incognita (PtI) & Cucumis melo L. & Azores & [22] \\
\hline M. inornata (ChIn) b & S. lycopersicum L. & Chile & - \\
\hline M. javanica $(\mathrm{PtJ})$ & S. tuberosum L. & Guarda & {$[22]$} \\
\hline
\end{tabular}

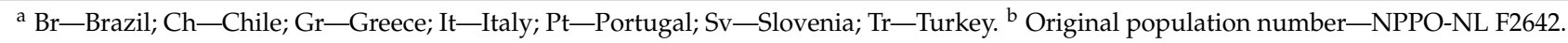

\subsection{Nematode Species Identification}

Before DNA extraction, the identification of all RKN isolates was confirmed by the biochemical electrophoretic analysis of the non-specific esterase phenotype of females, as previously described [27]. Five egg-laying females of each RKN isolate were handpicked from infected tomato roots and transferred to micro-hematocrit tubes with $5 \mu \mathrm{L}$ of $20 \%$ sucrose and $1 \%$ Triton X-100. The females were macerated, frozen and stored at $-20{ }^{\circ} \mathrm{C}$. The electrophoresis was carried out using the Mini-Protean Tetra Cell System (Bio-Rad Laboratories). The polyacrylamide gels were stained for esterase activity with $\alpha$-naphthyl acetate. Protein extracts from five females of $M$. javanica were included in each gel for reference.

\subsection{DNA Extraction}

Egg masses were handpicked from tomato cv. Coração-de-Boi infected roots, placed in a hatching chamber and kept in the dark $\left(25^{\circ} \mathrm{C}\right)$. Hatched second-stage juveniles (J2) were collected and stored at $-20^{\circ} \mathrm{C}$. Total genomic DNA was extracted from J2 of each Meloidogyne isolate using the DNeasy Blood \& Tissue Kit (QIAGEN). Genomic DNA was also extracted from galls of M. luci (isolate PtL1) and M. ethiopica (isolate BrEt) infected tomato roots. Single galls with single third-stage juvenile to young females without egg mass were handpicked, crushed with a piston, on ice, and then DNA was extracted using the DNeasy Plant Mini Kit (QIAGEN), according to the manufacturer's instructions.

\subsection{Random Amplified Polymorphic DNA (RAPD) Analysis}

Twenty-one random 10-mer oligo-nucleotide primers (Table 2) were used for RAPD M. luci (isolate PtL1) and M. ethiopica (isolate BrEt) genome screening to find DNA markers specific to $M$. luci.

PCR reactions were performed in $13 \mu \mathrm{L}$ volume containing $10 \mathrm{ng}$ of $M$. luci or M. ethiopica DNA, $1 \times$ buffer, $1.8 \mathrm{mM} \mathrm{MgCl}, 0.2 \mathrm{mM}$ dNTPs, $0.3 \mu \mathrm{M}$ of primer and 2 U BioTaq DNA polymerase (Bioline). The amplifications were carried out in a thermal cycler (Bio-Rad) using the following conditions: an initial denaturation at $94{ }^{\circ} \mathrm{C}$ for $5 \mathrm{~min}$, followed by 40 cycles of denaturation at $94^{\circ} \mathrm{C}$ for $30 \mathrm{~s}$, annealing at $39^{\circ} \mathrm{C}$ for $45 \mathrm{~s}$ and extension at $72{ }^{\circ} \mathrm{C}$ for $2 \mathrm{~min}$, and a final extension for $10 \mathrm{~min}$ at $72^{\circ} \mathrm{C}$. The PCR products were analyzed on $1.5 \%$ agarose gel electrophoresis in $1 \times$ TBE buffer stained with GreenSafe (Nzytech). The experiment was repeated twice to confirm the reproducibility of the results. 
Table 2. Random amplified polymorphic DNA primers used in this study.

\begin{tabular}{cc}
\hline Primer $\mathbf{N a m e}$ & Primer $^{\text {Sequence }} \mathbf{5}^{\prime} \rightarrow \mathbf{3}^{\prime} \mathbf{)}$ \\
\hline OPA-06 & GGTCCCTGAC \\
OPA-08 & GTGACGTAGG \\
OPA-09 & GGGTAACGCC \\
OPA-17 & GACCGCTTGT \\
OPAB-05 & CCCGAAGCGA \\
OPAS-09 & TGGAGTCCCC \\
OPB-01 & GTTTCGCTCC \\
OPB-14 & TCCGCTCTGG \\
OPC-06 & GAACGGACTC \\
OPC-08 & TGGACCGGTG \\
OPD-01 & ACCGCGAAGG \\
OPE-06 & AAGACCCCTC \\
OPE-07 & AGATGCAGCC \\
OPF-07 & CCGATATCCC \\
OPG-04 & AGCGTGTCTG \\
OPK-02 & GTCTCCGCAA \\
OPM-01 & GTTGGTGGCT \\
OPN-11 & CTCACGTTGG \\
OPO-06 & CCACGGGAAG \\
OPR-09 & TGAGCACGAG \\
OPY-11 & AGACGATGGG \\
\hline
\end{tabular}

\subsection{Cloning and Sequencing RAPD Fragment}

A RAPD amplification product present on $M$. luci and absent on M. ethiopica was purified from the agarose gel using the NucleoSpin ${ }^{\circledR}$ Gel and PCR Clean-up kit (Macherey Nagel), ligated into a pGEM ${ }^{\circledR}$-T Easy Vector (Promega) and transformed in Escherichia coli JM109 High Efficiency Competent Cells (Promega), following the manufacturer's instructions. Plasmid DNA was extracted from E. coli cells using a NZYMini Prep kit (Nzytech), and two positive clones were selected and were fully sequenced in both strands in an Automatic Sequencer 3730xl under BigDyeTM terminator cycling conditions at the Macrogen Company (Spain).

\subsection{Primer Design and PCR for Sequence Characterized Amplified Region (SCAR)}

Based on the obtained sequence, a pair of species-specific primers in the two extremes of the SCAR and spanning the OPY-11 RAPD primer sequence were designed using a Primer-BLAST tool [39]. These primers were then used in PCR. Amplifications were carried out using $50 \mathrm{ng}$ of extracted DNA and $2 \mathrm{U}$ of BioTaq DNA polymerase (Bioline) in $1 \times$ reaction buffer, $0.2 \mathrm{mM}$ each dNTPs, $1.8 \mathrm{mM} \mathrm{MgCl}_{2}$ and $0.2 \mu \mathrm{M}$ of each primer (Mlf $5^{\prime}$ ACTCCTGCGACCTCATGGCATTTA- ${ }^{\prime}$ and Mlr $5^{\prime}$-ACTCCTGCGAACACAACATTTACT$\left.3^{\prime}\right)$. Reactions were carried out in a thermal cycler (Bio-Rad) with an initial denaturation step of $94^{\circ} \mathrm{C}$ for 4 min followed by 35 reaction cycles of $94{ }^{\circ} \mathrm{C}$ for $30 \mathrm{~s}$, then annealed for $45 \mathrm{~s}$ at $70{ }^{\circ} \mathrm{C}$, with an extension at $72{ }^{\circ} \mathrm{C}$ for $45 \mathrm{~s}$ and a final extension at $72{ }^{\circ} \mathrm{C}$ for $10 \mathrm{~min}$. The specificity of the designed primers was tested using DNA from nine $M$. luci isolates and one isolate of M. arenaria, M. chitwoodi, M. enterolobii, M. ethiopica, M. hapla, M. hispanica, M. incognita, M. inornata and M. javanica (Table 1).

Additionally, DNA from the galls of tomato roots infected with M. luci (isolate PtL1) or M. ethiopica (isolate BrEt) were amplified using the same amplification conditions of SCARPCR. A positive control was included (DNA from J2 of PtL1). To increase the sensitivity of the test, a second PCR was performed using the same PCR conditions as described above, with $1 \mu \mathrm{L}$ of the first PCR reaction (or $1 \mu \mathrm{L}$ of 1:10 dilution for positive control) used as template.

The amplification of the COI of the mtDNA region was also performed in order to confirm the success of nematode DNA extraction from the J2/galls of non-target samples using primers and PCR conditions described in [27] (data not shown). 
All the PCR products were analyzed on $1 \%$ agarose gel electrophoresis in $1 \times$ TBE buffer stained with GreenSafe. The experiments were repeated with at least two biological replicates, with DNA extracted from two different samples for each isolate.

\section{Results}

\subsection{Esterase Phenotypes}

The identification of all Meloidogyne isolates was confirmed by the esterase phenotypes (Figure 1). The three esterase bands (J3) observed in the M. javanica isolate were used as a reference phenotype, which allowed for the determination of the relative position of the bands perceived in the Meloidogyne isolates.
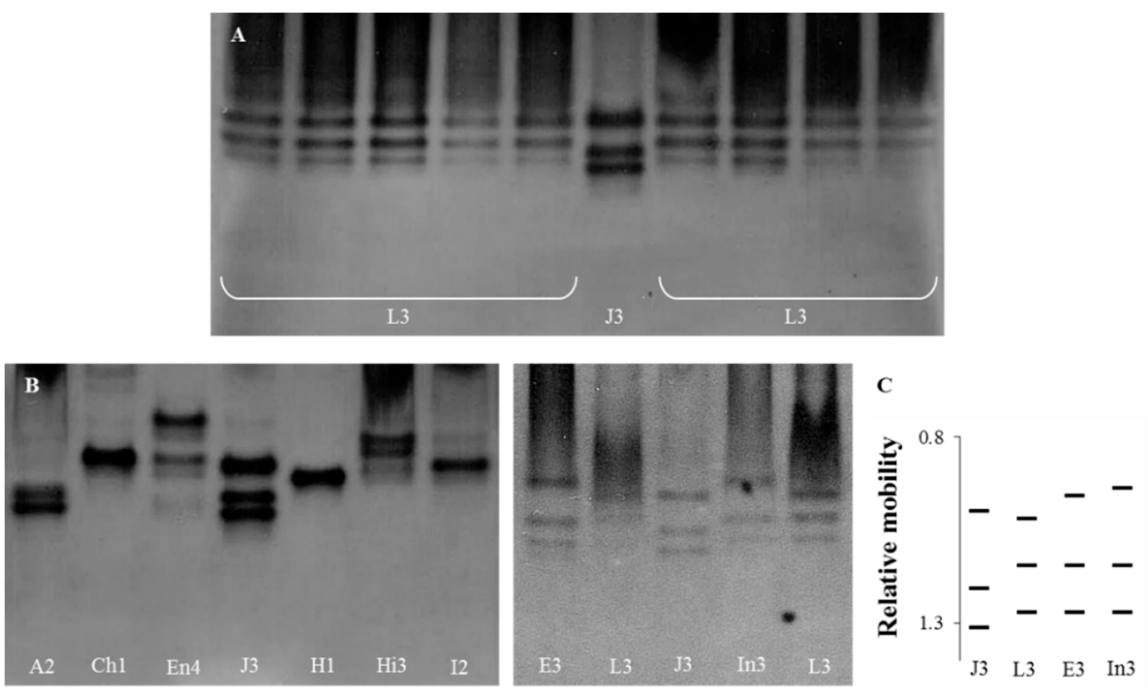

Figure 1. Esterase phenotypes of protein homogenates from five egg-laying females of Meloidogyne species isolates. From left to right: (A) L3-M. luci (isolates PtL1, PtL2, PtL3, BrL and GrL1), J3M. javanica (reference isolate); L3-M. luci (isolates GrL2, ItL, SvL and TrL); (B) A2-M. arenaria; Ch1-M. chitwoodi; En4-M. enterolobii; J3-M. javanica (reference isolate); H1-M. hapla; Hi3M. hispanica; I2-M. incognita; E3-M. ethiopica; L3-M. luci (PtL1); J3-M. javanica (reference isolate); and In3-M. inornata. (C) Relative mobility of J3, L3, E3 and In3. For isolate codes see Table 1.

In the M. luci isolates, three bands of esterase activity were detected, corresponding to the phenotype L3, attributed to M. luci from Brazil (Figure 1A). The other nine Meloidogyne spp. isolates exhibited 22 bands of esterase activity, comprising nine phenotypes based on single bands or combinations. All the species displayed distinct and typical species-specific phenotypes, as previously described: $M$. arenaria (A2), M. chitwoodi (Ch1), M. enterolobii (En4), M. ethiopica (E3), M. javanica (J3), M. hapla (H1), M. hispanica (Hi3), M. incognita (I2) and M. inornata (In3) (Figure 1). The esterase phenotype of M. luci was distinct from those of M. ethiopica and M. inornata and from the other Meloidogyne spp. (Figure 1B).

\subsection{Selection of Meloidogyne luci Specific RAPD Fragment}

A total of 21 random 10-mer oligo-nucleotide primers were used to find a speciesspecific marker for M. luci (Table 2). Most primers were unable to differentiate M. luci from M. ethiopica or the results were not reproducible and intraspecific variability among M. luci isolates was also found (data not shown), except for primer OPY-11. The primer OPY-11 resulted in different band patterns for M. luci (isolate PtL1) and M. ethiopica (isolate $\mathrm{BrEt}$ ) isolates (Figure 2). A consistent species-specific band of $\sim 770$-bp was present in the M. luci isolate and absent in the M. ethiopica isolate. This DNA fragment was cloned and the sequence was determined to be used as a M. luci SCAR marker. 


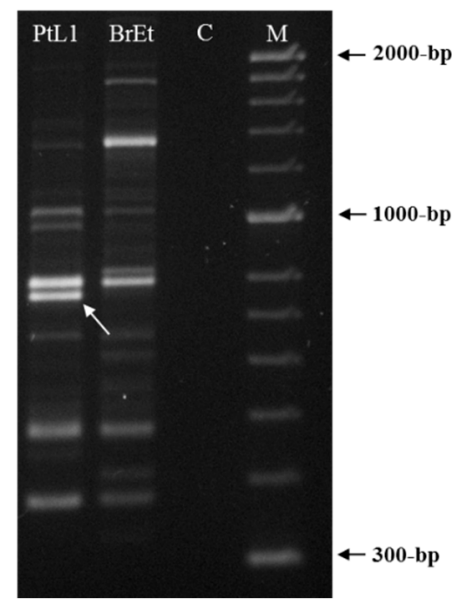

Figure 2. RAPD patterns for Meloidogyne luci (isolate PtL1) and M. ethiopica (isolate BrEt) obtained with primer OPY-11. The M. luci specific $\sim 770 \mathrm{bp}$ fragment is shown with an arrowhead. For isolate codes, see Table 1. C—Negative control; M-DNA marker (HyperLadder II, Bioline).

\subsection{Meloidogyne luci SCAR Marker and Species-Specific Detection Assay}

Two sequences of $771 \mathrm{bp}$ were obtained by sequencing two clones of the selected RAPD fragment and submitted to GenBank under the accession numbers MW922841 and MW922842. Based on these sequences, the primers Mlf (5'-ACTCCTGCGACCTCATGGCA TTTA-3 ${ }^{\prime}$ ) and Mlr (5'-ACTCCTGCGAACACAACATTTACT- $\left.3^{\prime}\right)$ were designed and used for the PCR amplification of the M. luci SCAR marker (771 bp). This was successfully amplified for all $M$. luci isolates with no amplification registered for the other Meloidogyne spp., namely, M. arenaria, M. chitwoodi, M. enterolobii, M. ethiopica, M. hapla, M. hispanica, M. incognita, M. inornata and M. javanica (Figures 3 and 4). Additionally, the proper amplification of the M. luci SCAR-marker was also successfully achieved using DNA from the galls of $M$. luci infected tomato roots. On the other hand, no amplification was obtained with the DNA from the galls of the M. ethiopica infected tomato roots (Figure 5).
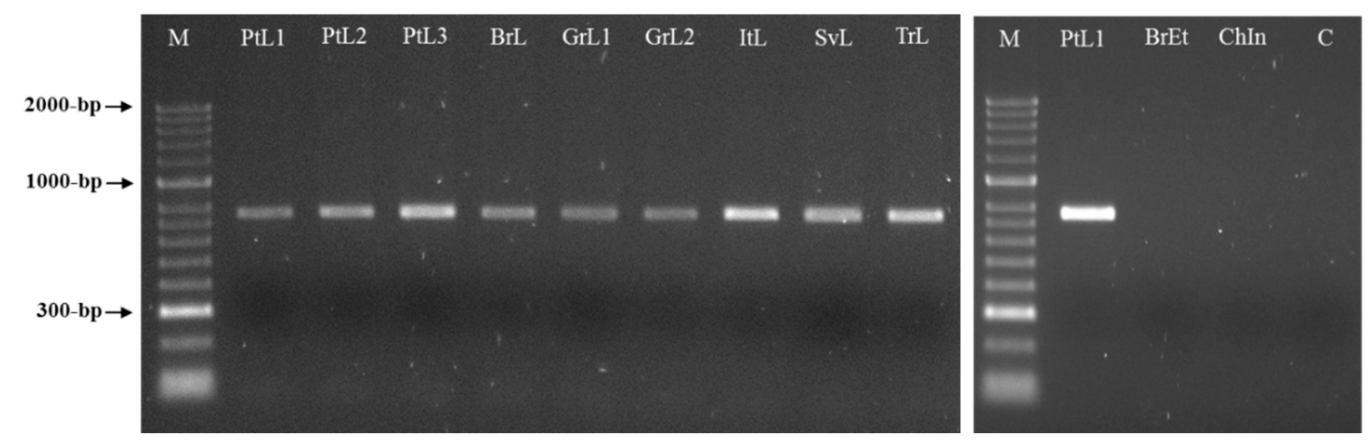

Figure 3. SCAR-PCR products ( 770 bp specific fragment) for Meloidogyne luci (isolates PtL1, PtL2, $\mathrm{PtL} 3, \mathrm{BrL}, \mathrm{GrL1}$, GrL2, ItL, SvL and TrL), M. ethiopica (isolate BrEt) and M. inornata (isolate ChIn) using the species-specific primer pair Mlf/r. For isolate codes, see Table 1. M-DNA marker (HyperLadder II, Bioline); C-Negative control. 


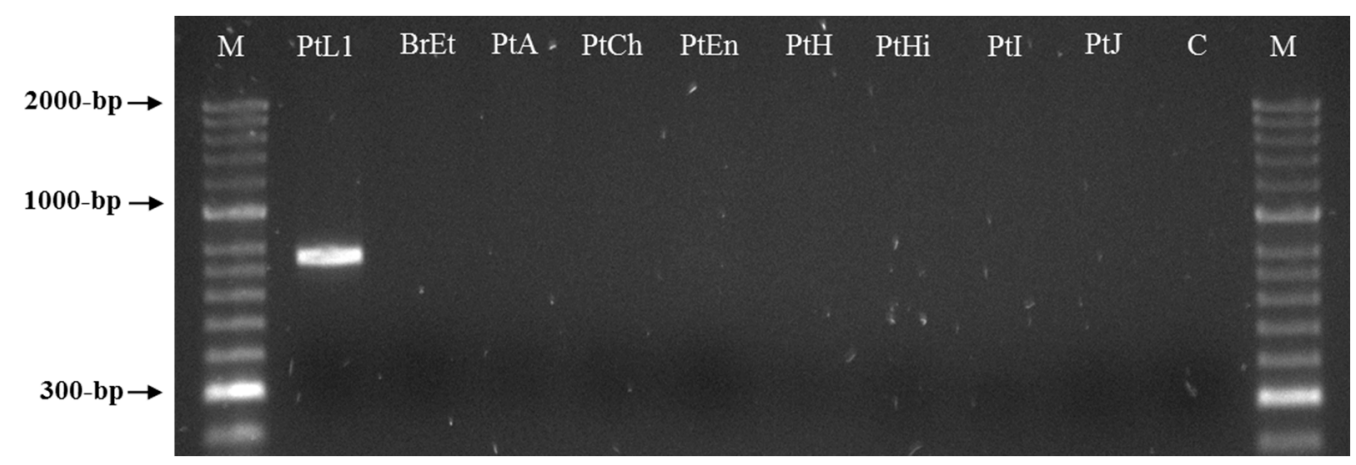

Figure 4. SCAR-PCR product ( 770 bp specific fragment) for Meloidogyne luci (isolate PtL1) and other Meloidogyne species (isolates $\mathrm{BrEt}, \mathrm{PtA}, \mathrm{PtCh}, \mathrm{PtEn}, \mathrm{PtH}, \mathrm{PtHi}, \mathrm{PtI}$ and $\mathrm{PtJ}$ ) included in the study, using the species-specific primer pair Mlf/r. For isolate codes see Table 1. M-DNA marker (HyperLadder II, Bioline); C-Negative control.

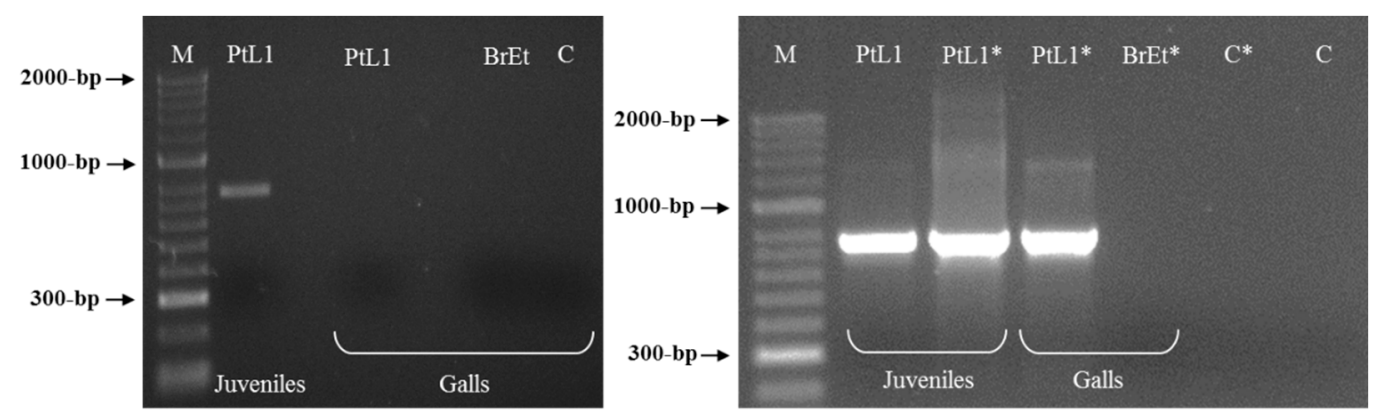

Figure 5. PCR product for Meloidogyne luci (isolate PtL1) infected tomato root (individual gall) using the species-specific primer pair Mlf/r. Tomato infected root with M. ethiopica (isolate BrEt) was included for comparison. For isolate codes see Table 1. ${ }^{*}$ Re-amplification; M-DNA marker (HyperLadder II, Bioline); C-Negative control.

\section{Discussion}

Meloidogyne luci is a polyphagous species with a wide host range including plants from several botanical families. It affects important crops such as potato, tomato, maize, bean and kiwifruit, among others [24,27-30,40]. As M. luci has been included in the EPPO Alert List of harmful organisms since 2017, due to its increasing importance and potential to cause serious damage to agriculture [41], it is crucial to have rapid and discriminative methods for detecting the presence of this emerging RKN.

Meloidogyne luci and M. ethiopica are morphologically very similar, and their molecular relationship has been the subject of several studies ever since the M. luci description, with different DNA regions being characterized, namely: internal transcribed spacer 1 (ITS1) rRNA and D2-D3 fragment of 28S rRNA regions [17,25]; mitochondrial DNA (mtDNA) cytochrome oxidase subunit II (COII) [15,27]; and ITS1-5.8S-ITS2 rRNA region and cytochrome oxidase subunit I (COI) mtDNA region [27]. However, the ITS and D2D3 fragments of the 28S rRNA region were considered inappropriate for studying the relationships among these closely related RKN species [15,27]. Gerič Stare et al. [15] selected the mtDNA COII region as the most useful for the identification and differentiation of M. luci from closely related species, whereas Maleita et al. [27] designated the mtDNA $\mathrm{COI}$ region as the most effective. Due to a lack of consensus about the true significance of the close relationship between M. luci, M. ethiopica and M. inornata, Gerič Stare et al. [16] proposed the integration of these three species in a separate group, forming the M. ethiopica group, based on a unique structure of map-1 genes when compared to the other tropical RKN species. Furthermore, Gerič Stare et al. [16] developed a pair of primers, designed on COII mtDNA region, for the molecular detection of M. ethiopica group by PCR. The use of these primers was further validated for the detection of nematodes of the M. ethiopica group 
by real-time PCR, but they do not allow the discrimination of species within the group [34]. In order to obtain insight on the phylogeny of the RKN, Álvarez-Ortega et al. [42] used a multigene dataset (18S rRNA, ITS1 rRNA, D2-D3 expansion segments of 28S rRNA, COI gene and COII-16S rRNA) and incorporated the representatives of the M. ethiopica group in the same clade with other 17 RKN species distributed in warmer climates.

In the present study, a M. luci specific SCAR marker (771 bp) was obtained with the OPY-11 RAPD primer and somewhat similar sequences of this SCAR product were found in the recently published M. luci draft genome [43]. Based on this SCAR product, species-specific primers for $M$. luci were designed, providing the first diagnostic molecular method for the specific detection of $M$. luci and allowing for the discrimination of this species from the closely related M. ethiopica and M. inornata [16]. Although a SCAR marker has been previously developed for the specific detection of M. ethiopica [13], the discrimination/identification of the three species within the M. ethiopica group, until now, was only possible by the isoenzyme analysis. Nevertheless, the esterase phenotype assessment has limitations, as it requires young females and a gel comparative analysis of the obtained patterns for the different species. The first band of the esterase phenotype of $M$. luci is located at the same level of the first band of $M$. javanica (reference isolate), whereas the first bands of $M$. ethiopica and $M$. inornata are located above, making it almost impossible to distinguish them when they are not in the same gel $[14,15,17,27,30,44,45]$.

\section{Conclusions}

The M. luci species-specific PCR based assay, described in this study, is accurate and highly sensitive since it requires minimal DNA templates from nematode eggs, juveniles, females or infected plant material for the amplification and detection of target sequences. The specificity of the developed primer pair Mlf/ $\mathrm{r}$ was also validated by including $M$. luci isolates from different origins and hosts and other seven isolates from RKN species than M. ethiopica and M. inornata.

The application of a species-specific PCR-SCAR for the M. luci detection on the galls of infected tomato roots was also investigated, and our findings revealed that the molecular differentiation of M. luci in galls is reachable and that the methodology can be adopted in routine inspections or for monitoring distribution and spread of this emerging plant pathogen.

Author Contributions: Conceptualization, C.M.; methodology, C.M., J.M.S.C., L.R. and I.E.; validation, C.M. and I.E.; formal analysis, C.M., J.M.S.C., L.R., I.E. and I.A.; investigation, C.M., J.M.S.C., L.R., I.E. and I.A.; resources, C.M., I.E. and I.A.; writing—original draft preparation, C.M.; writingreview and editing, C.M., J.M.S.C. and I.E.; visualization, C.M., J.M.S.C., L.R., I.E. and I.A.; supervision, I.A.; project administration, C.M. and I.E.; funding acquisition, C.M. and I.E. All authors have read and agreed to the published version of the manuscript.

Funding: This research was supported by the CFE, Department of Life Sciences, UC; by the CIEPQPF, Department of Chemical Engineering, UC; by FEDER funds through the Portugal 2020 (PT 2020) "Programa Operacional Factores de Competitividade 2020"(COMPETE2020) and "Fundação para a Ciência e a Tecnologia" (FCT, Portugal) under the contracts UIDB/04004/2020, UIDB/00102/2020, POCI-01-0145-FEDER-031946 (Ref. PTDC/ASP-PLA/31946/2017) and CEECIND/02082/2017 (to I. Esteves); by Project ReNATURE-Valorization of the Natural Endogenous Resources of the Centro Region (Centro2020, Centro-01-0145-FEDER-000007); and by the "Instituto do Ambiente, Tecnologia e Vida".

Institutional Review Board Statement: Not applicable.

Informed Consent Statement: Not applicable.

Data Availability Statement: Sequence data that support part of the findings of this study are available in GenBank under the accession numbers MW922841 and MW922842. Other data generated during this study are included in this article. 
Acknowledgments: The authors are grateful to Regina Carneiro for providing the M. ethiopica and M. luci isolates from Brazil; Isabel Luci da Conceição, Saša Širca and Gökhan Aydınlı for providing the Greek, Slovenian and Turkish isolates of M. luci; and Gerrit Karssen and Evelyn van Heese for providing the M. inornata isolate.

Conflicts of Interest: The authors declare no conflict of interest. The funders had no role in the design of the study; in the collection, analyses, or interpretation of data; in the writing of the manuscript; or in the decision to publish the results.

\section{References}

1. Elling, A.A. Major emerging problems with minor Meloidogyne species. Phytopathology 2013, 103, 1092-10102. [CrossRef]

2. Jones, J.T.; Haegeman, A.; Danchin, E.G.J.; Gaur, H.S.; Helder, J.; Jones, M.G.K.; Kikuchi, T.; Manzanilla-López, R.; Palomares-Rius, J.E.; Wesemael, W.M.L. Top 10 plant-parasitic nematodes in molecular plant pathology. Mol. Plant. Pathol. 2013, 14, 946-961. [CrossRef] [PubMed]

3. Ghaderi, R.; Karssen, G. An updated checklist of Meloidogyne Göldi, 1887 species, with a diagnostic compendium for second-stage juveniles and males. J. Crop. Prot. 2020, 9, 183-193.

4. EPPO. EPPO A2 List of Pests Recommended for Regulation as Quarantine Pests. 2020. Available online: https://www.eppo.int/ ACTIVITIES/plant_quarantine/A2_list (accessed on 15 April 2021).

5. Carneiro, R.M.D.G.; Almeida, M.R.A.; Quénéhervé, T.P. Enzyme phenotypes of Meloidogyne spp. populations. Nematology 2000, 2, 645-654. [CrossRef]

6. Blok, V.C.; Powers, T.O. Biochemical and molecular identification. In Root Knot Nematodes, 1st ed.; Perry, R.N., Moens, M., Star, J., Eds.; CABI International: London, UK, 2009; pp. 98-112.

7. Powers, T.O.; Harris, T.S. A polymerase chain reaction method for identification of five major Meloidogyne species. J. Nematol. 1993, 25, 1-6.

8. Zijlstra, C.; Donkers-Venne, D.T.H.M.; Fargette, M. Identification of Meloidogyne incognita, M. javanica and M. arenaria using sequence characterized amplified region (SCAR) based PCR assays. Nematology 2000, 2, 847-853.

9. Randig, O.; Bongiovanni, M.; Carneiro, R.M.D.G.; Castagnone-Sereno, P. Genetic diversity of root-knot nematodes from Brazil and development of SCAR markers specific for the coffee-damaging species. Genome 2002, 45, 862-870. [CrossRef]

10. Zijlstra, C.; van Hoof, R.; Donkers-Venne, D. A PCR test to detect the cereal root-knot nematode Meloidogyne naasi. Eur. J. Plant. Pathol. 2004, 110, 855-860. [CrossRef]

11. Xu, J.; Liu, P.; Meng, Q.; Long, H. Characterisation of Meloidogyne species from China using isozyme phenotypes and amplified mitochondrial DNA restriction fragment length polymorphism. Eur. J. Plant. Pathol. 2004, 110, 309-315. [CrossRef]

12. Adam, M.A.M.; Phillips, M.S.; Blok, V.C. Molecular diagnostic key for identification of single juveniles of seven common and economically important species of root-knot nematode (Meloidogyne spp.). Plant. Pathol. 2007, 56, 190-197. [CrossRef]

13. Correa, V.R.; Mattos, V.S.; Almeida, M.R.A.; Santos, M.F.A.; Tigano, M.S.; Castagnone-Sereno, P.; Carneiro, R.M.D.G. Genetic diversity of the root-knot nematode Meloidogyne ethiopica and development of a species-specific SCAR marker for its diagnosis. Plant. Pathol. 2014, 63, 476-483. [CrossRef]

14. Janssen, T.; Karssen, G.; Verhaeven, M.; Coyne, D.; Bert, W. Mitochondrial coding genome analysis of tropical root-knot nematodes (Meloidogyne) supports haplotype based diagnostics and reveals evidence of recent reticulate evolution. Sci. Rep. 2016, 6, 22591. [CrossRef] [PubMed]

15. Gerič Stare, B.; Strajnar, P.; Susic, N.; Urek, G.; Širca, S. Reported populations of Meloidogyne ethiopica in Europe identified as Meloidogyne luci. Plant. Dis. 2017, 101, 1627-1632. [CrossRef]

16. Gerič Stare, B.; Aydınl1, G.; Devran, Z.; Mennan, S.; Strajnar, P.; Urek, G.; Širca, S. Recognition of species belonging to Meloidogyne ethiopica group and development of a diagnostic method for its detection. Eur. J. Plant. Pathol. 2019, 154, 621-633. [CrossRef]

17. Carneiro, R.M.D.G.; Correa, V.R.; Almeida, M.R.A.; Gomes, A.C.M.M.; Deimi, A.M.; Castagnone-Sereno, P.; Karssen, G. Meloidogyne luci n. sp. (Nematoda: Meloidogynidae), a root-knot nematode parasitising different crops in Brazil, Chile and Iran. Nematology 2014, 16, 289-301. [CrossRef]

18. Širca, S.; Urek, G.; Karssen, G. First report of the root-knot nematode Meloidogyne ethiopica on tomato in Slovenia. Plant. Dis. 2004, 88, 680. [CrossRef] [PubMed]

19. Strajnar, P.; Širca, S.; Gerič Stare, B.; Urek, G. Characterization of the root-knot nematode, Meloidogyne ethiopica Whitehead, 1968, from Slovenia. Russ. J. Nematol. 2009, 17, 135-142.

20. Strajnar, P.; Širca, S.; Knapič, M.; Urek, G. Effect of Slovenian climatic conditions on the development and survival of the root-knot nematode Meloidogyne ethiopica. Eur. J. Plant. Pathol. 2011, 129, 81-88. [CrossRef]

21. Conceição, I.L.; Tzortzakakis, E.A.; Gomes, P.; Abrantes, I.; da Cunha, M.J. Detection of the root-knot nematode Meloidogyne ethiopica in Greece. Eur. J. Plant. Pathol. 2012, 134, 451-457. [CrossRef]

22. Maleita, C.M.; Simões, M.J.; Egas, C.; Curtis, R.H.C.; de O. Abrantes, I.M. Biometrical, biochemical, and molecular diagnosis of Portuguese Meloidogyne hispanica isolates. Plant. Dis. 2012, 96, 865-887. [CrossRef]

23. Aydınlı, G.; Mennan, S.; Devran, Z.; Širca, S.; Urek, G. First report of the root-knot nematode Meloidogyne ethiopica on tomato and cucumber in Turkey. Plant. Dis. 2013, 97, 1262. [CrossRef] 
24. Bellé, C.; Brum, D.; Groth, M.Z.; Barros, D.R.; Kaspary, T.E.; Schafer, J.T.; Gomes, C.B. First report of Meloidogyne luci parasitizing Glycine max in Brazil. Plant. Dis. 2016, 100, 2174. [CrossRef]

25. Machado, A.C.Z.; Dorigo, O.F.; Carneiro, R.M.D.G.; Araújo, J.V.F. Meloidogyne luci, a new infecting nematode species on common bean fields at Paraná State, Brazil. Helminthologia 2016, 53, 207-210. [CrossRef]

26. Gerič Stare, B.; Strajnar, P.; Širca, S.; Susic, N.; Urek, G. Record of a new location for tropical root knot nematode Meloidogyne luci in Slovenia. EPPO Bull. 2018, 48, 135-137. [CrossRef]

27. Maleita, C.; Esteves, I.; Cardoso, J.M.S.; Cunha, M.J.; Carneiro, R.M.D.G.; Abrantes, I. Meloidogyne luci, a new root-knot nematode parasitizing potato in Portugal. Plant. Pathol. 2018, 67, 366-376. [CrossRef]

28. Bellé, C.; Balardin, R.R.; Ramos, R.F.; Sobucki, L.; Gabriel, M.; Antoniolli, Z.I. First report of Meloidogyne luci (Nematoda: Meloidogynidae) parasitizing Luffa cylindrica in Brazil. Plant. Dis. 2019, 103, 2695. [CrossRef]

29. Bellé, C.; Ramos, R.F.; Balardin, R.R.; Nora, D.D.; Gabriel, M.; Antoniolli, Z.I. Reproduction of the root-knot nematodes, Meloidogyne ethiopica and Meloidogyne luci, on common bean cultivars. Revista de Ciências Agrárias 2019, 42, 1052-1058. [CrossRef]

30. Santos, D.; Correia, A.; Abrantes, I.; Maleita, C. New hosts and records in Portugal for the root-knot nematode Meloidogyne luci. J. Nematol. 2019, 51, e2019-03. [CrossRef]

31. Gonçalves, A.R.; Conceição, I.L.; Kormpi, M.; Tzortzakakis, E.A. Lavandula angustifolia and Oxalis pes-caprae, hosts of Meloidogyne hapla and Meloidogyne javanica-A note for Meloidogyne luci in Greece. Hell. Plant. Prot. J. 2020, 13, 78-82. [CrossRef]

32. Susič, N.; Širca, S.; Urek, G.; Gerič Stare, B. Senecio vulgaris L. recorded as a new host plant for the root-knot nematode Meloidogyne luci. Acta Agric. Slov. 2020, 115, 495-497. [CrossRef]

33. Rusinque, L.; Nóbrega, F.; Cordeiro, L.; Serra, C.; Inácio, M.L. First detection of Meloidogyne luci (Nematoda: Meloidogynidae) parasitizing potato in the Azores, Portugal. Plants 2021, 10, 99. [CrossRef] [PubMed]

34. Žibrat, U.; Gerič Stare, B.; Knapič, M.; Susič, N.; Lapajne, J.; Širca, S. Detection of root-knot nematode Meloidogyne luci infestation of potato tubers using hyperspectral remote sensing and real-time PCR molecular methods. Remote Sens. 2021, 13, 1996. [CrossRef]

35. da Conceição, I.L.; da Cunha, M.J.; Feio, G.; Correia, M.; dos Santos, M.C.V.; Isabel, M.D.O.; Santos, M.S.D.A. Root-knot nematodes, Meloidogyne spp., on potato in Portugal. Nematology 2009, 11, 311-313.

36. Santos, D.; Abrantes, I.; Maleita, C. The quarantine root knot nematode Meloidogyne enterolobii-A potential threat to Portugal and Europe. Plant. Pathol. 2019, 68, 1607-1615. [CrossRef]

37. Carneiro, R.M.D.G.; Gomes, C.B.; Almeida, M.R.A.; Gomes, A.C.M.M.; Martins, I. Primeiro registro de Meloidogyne ethiopica, Whitehead, 1968 em plantas de quivi no Brasil e reação de diferentes plantas cultivadas. Nematol. Bras. 2003, 27, 151-158.

38. Abrantes, I.D.O.; dos Santos, M.V.; da Conceição, I.L.P.M.; Santos, M.D.A.; Vovlas, N. Root-knot and other plant parasitic nematodes associated with fig trees in Portugal. Nematol. Mediterr. 2008, 36, 131-136.

39. Ye, J.; Coulouris, G.; Zaretskaya, I.; Cutcutache, I.; Rozen, S.; Madden, T. Primer-BLAST: A tool to design target-specific primers for polymerase chain reaction. BMC Bioinform. 2012, 13, 134. [CrossRef]

40. EPPO. 2016. Available online: https://gd.eppo.int/reporting/article-5957 (accessed on 4 July 2021).

41. EPPO. 2017. Available online: https://gd.eppo.int/reporting/article-6186 (accessed on 4 July 2021).

42. Álvarez-Ortega, S.; Brito, J.A.; Subbotin, S.A. Multigene phylogeny of root-knot nematodes and molecular characterization of Meloidogyne nataliei Golden, Rose \& Bird, 1981 (Nematoda: Tylenchida). Sci Rep. 2019, 9, 11788. [PubMed]

43. Susič, N.; Koutsovoulos, G.D.; Riccio, C.; Danchin, E.; Blaxter, M.L.; Lunt, D.H.; Strajnar, P.; Širca, S.; Urek, G.; Stare, B.G. Genome sequence of the root-knot nematode Meloidogyne luci. J. Nematol. 2020, 52, e2020-25. [CrossRef]

44. Carneiro, R.; Karssen, G.; Gomes, A.C.; de Lourdes Mendes, M.; Almeida, M.R.; dos Santos, M. Additional information on Meloidogyne inornata Lordello, 1956 (Tylenchida: Meloidogynidae) and its characterisation as a valid species. Nematology 2008, 10, 123-136. [CrossRef]

45. Camara, G.R.; Carvalho, A.H.O.; Teixeira, A.G.; Ferreira, M.L.S.M.; Oliveira, F.L.; de Moraes, W.B.; Alves, F.R. First report of Meloidogyne inornata on Smallanthus sonchifolius in Brazil. Plant. Dis. 2020, 104, 595. [CrossRef] 